\title{
The patterns of consumption of alcohol among employ- ees of a Brazilian public university
}

Padrão do consumo de álcool entre trabalhadores de uma universidade pública brasileira Patrón de consumo de alcohol entre los trabajadores de una universidad pública brasileña Fernanda Matos Fernandes Castelo Branco*iD; Francisca Luana de Sousa Farias**iD; Carlos Manuel Sanchez Dutok***iD; Tancredo Castelo Branco Neto****iD; Divane de Vargas***** (D); Tereza Maria Mendes Diniz de Andrade Barroso****** (D)

\section{Abstract}

Background: Alcohol is an easily accessible legal drug, widely used, and considered a public health problem worldwide. Therefore, there is a growing concern with this consumption among employees of educational institutions. Objective: To identify the pattern of consumption of alcohol among employees of a public university.

Methodology: A cross-sectional study. Fifty-three online questionnaires were applied to administrative technicians and lecturers of a public university in northern Brazil, evaluated through the Alcohol Use Disorders Identification Test (AUDIT). The chi-squared test and Fisher's exact test were used, with a $p$-value of $\leq 0.05$ to test the level of significance of the variables and the AUDIT score.

Results: Among the participants, $68 \%$ have a low-risk use or do not consume alcohol, $24 \%$ present a risky use, $2 \%$ harmful consumption, and $6 \%$ probable dependence. Only the children variable showed a statistical association with the problematic use of alcohol.

Conclusion: The results suggest a problematic consumption of alcohol in a significant portion of the sample studied, resulting in the need for the implementation of brief interventions in the population studied.

Keywords: occupational health; universities; alcohol drinking

\section{Resumo}

Enquadramento: $\mathrm{O}$ álcool é uma droga lícita, de fácil acesso, amplamente utilizada e considerada um problema de saúde pública mundial. Assim, há uma crescente preocupação com este consumo entre os trabalhadores das instituições de ensino.

Objetivo: Identificar o padrão do consumo de álcool nos trabalhadores de uma universidade pública.

Metodologia: Estudo transversal. Foram aplicados 53 questionários online, a técnicos administrativos e docentes de uma universidade pública no norte do Brasil, avaliados através do Alcohol Use Disorders Identification Test (AUDIT). Aplicou-se o teste qui-quadrado e exato de Fisher, com $p$-value $\leq 0,05$ para testar o nível de significância das variáveis e o score do AUDIT.

Resultados: De entre os participantes, 68\% têm uma utilização de baixo risco ou nấo consomem, $24 \%$ apresentam consumo de risco, $2 \%$ consumo nocivo e $6 \%$ provável dependência. Apenas a variável possuir filhos apresentou associação estatística com uso problemático de álcool.

Conclusáo: Os resultados sugeriram um consumo problemático de álcool numa parcela significativa da amostra estudada, sendo necessária a implementaçáo de intervençóes breves na população estudada.

Palavras-chave: saúde do trabalhador; universidades; consumo de álcool

*Ph.D., Lecturer, Federal University of Amapá, 68980-000, Amapá, Brazil [fmfernandescb@ gmail.com]. (D) https://orcid.org/0000-0002-9074-0963. Contribution for the article: literature search; data collection, statistical treatment and assessment; data analysis, article writing. Address for correspondence: BR 156, nº 3051, 68980-000, Oiapoque - Amapá, Brasil.

**Bachelor, RN, Federal University of Amapá, 68980-000, Amapá, Brazil [luanaoiapoque@ hotmail.com]. (1) https://orcid.org/0000-0003-1597-0029. Contribution to the article: literature search; data collection, data analysis, article writing.

***:Ph.D., Lecturer, Federal University of Amapá, 68980-000,Amapá, Brazil [cmdutok@gmail com]. D https://orcid org/0000-0001-6712-3185. Contribution to the article: literature search; statistical treatment and assessment; data analysis, article writing.

*****ostgrad, Lecturer, Federal University of Amapá, 68980-000, Amapá, Brazil [tcbranconeto@gmail.com]. (1) https://orcid.org/0000-0002-5675-7219. Contribution to the article: literture search; statistical treatment and assessment; data analysis, article writing

******* Ph.D., Lecturer, Nursing School of the University of São Paulo, 05403-000, São Paulo, Brazil [vargas@usp.br]. (D https://orcidoro/0000-0003-3140-8394. Contribution to the artcle: data analysis, discussion of results, overall article analysis.

******:Ph.D., Adjunct Professor, Nursing School of Coimbra, 3046-851, Coimbra, Portugal [tbarroso@esenfc.pt]. D https://orcid.org/0000-0002-9411-6113. Contribution to the article: data analvsis, discussion of results, and overall article analvsis.

\section{Resumen}

Marco contextual: El alcohol es un producto lícito, de fácil acceso, ampliamente utilizado y considerado un problema de salud pública mundial. Por ello, existe una creciente preocupación por el consumo de alcohol entre los trabajadores de las instituciones educativas.

Objetivo: Identificar el patrón de consumo de alcohol entre los trabajadores de una universidad pública.

Metodología: Estudio transversal. Se aplicaron 53 cuestionarios en línea a técnicos administrativos y profesores de una universidad pública del norte de Brasil, y se evaluaron a través de la prueba Alcohol Use Disorders Identification Test (AUDIT). Se aplicó la prueba de la ji al cuadrado y la prueba exacta de Fisher, con el valor $p \leq$ 0,05 para probar el nivel de significación de las variables y la puntuación AUDIT.

Resultados: Entre los participantes, el 68\% muestra un uso de bajo riesgo o no consume, el $24 \%$ un consumo de riesgo, el $2 \%$ un consumo nocivo y el $6 \%$ una posible dependencia. Solo la variable tener hijos tenía una asociación estadística con el consumo problemático de alcohol.

Conclusión: Los resultados sugirieron un consumo problemático de alcohol en una parte significativa de la muestra estudiada, lo que requirió la implementación de intervenciones breves en la población estudiada.

Palabras clave: salud laboral; universidades; consumo de alcohol 


\section{Introduction}

Alcohol is considered worldwide a public health problem, causing severe consequences at the individual and collective levels. Currently, according to the report of the World Health Organization (WHO), approximately 2.3 billion people drink alcohol, more than half of the population in just three regions of the World - Americas, Asia and Western Pacific.

This same WHO report (2018) pointed out the negative impacts on population health, showing that the burden of diseases and injuries related to the alcohol was more prevalent in the African region, while the deaths and years of life lost due to disability were higher in the European Region (10.1\% and $10.8 \%$, respectively), followed by the Americas region, with 5.5\% (deaths) and $6.7 \%$ (disability).

In Brazil, approximately $40 \%$ of the population consumed alcohol in the last year.

A recent estimate on the consumption of alcohol in Brazil was held by the Surveillance of Risk Factors and Protection for Chronic Diseases through Telephone Survey (VIGITEL). This survey showed that the occasional risk drinking (intake of four or more doses for women, or five or more doses for men, on the same occasion) ranged from $14.5 \%$ in a capital city located in northern Brazil to $24.9 \%$ in another location in the northeast region of Brazil (Ministério da Saúde, 2017).

According to the $2^{\text {nd }}$ National Survey of Alcohol and Other Drugs, Brazil, in the last 10 years (before the data collection from this study), presented economic growth, the greatest ever recorded, thus showing that a higher income per capita was associated with the increase in consumption of alcohol, making the country a promising market for the alcohol industry (Laranjeira, 2014).

Therefore, consumption of alcohol reaches the population in its entirety, including children, adolescents, and even the economically active population, which generally involves students and employees (Lopes \& Silva, 2018; Laranjeira, 2014; Hernandez Reyes, Hernandez Castro, \& Aguila Gurierres, 2015).

Thus, understanding the adverse effects resulting from consumption of alcohol should be considered, in order to avoid damages associated with the use of this substance, since there are few studies regarding the use of psychoactive substances among lecturers, although these professionals manifest an intense and stressful work dynamics (Franco \& Monteiro, 2016).

Therefore, it is necessary to focus on the health of employees of educational institutions, due to the peculiarities of their work, such as the professional routine and adopted behaviors, including the use of psychoactive substances, such as alcohol, which is an easily accessible legal drug. It is, then, obviously pertinent to obtain in-depth knowledge about this phenomenon, in order to fund the development of public policies directed at the prevention and treatment of the suffered consequences.

Therefore, taking into account the context described above, and given the lack of research among employees of a higher education institution in the French-Brazilian border, this type of data collection was deemed essential. As a result, based on the elucidation of the results, strategies can be devised to improve the quality of life of these professionals, including feasible measures to prevent further damage and losses resulting from alcohol abuse and, where appropriate, to develop preventive and health-promoting measures, such as the implementation of brief interventions (BI) within this work context.

Thus, the objective of this study is to identify the pattern of consumption of alcohol among employees of a public university in northern Brazil.

\section{Background}

Understanding the damage associated with alcohol use is relevant for the prevention of harmful effects of consumption of this substance. Thus, the elaboration of drinking patterns is established, observing the medical and psychosocial aspects (Franco \& Monteiro, 2016).

WHO divides the drinking patterns into four categories: 1) Low-risk drinking (by individuals who consume low doses and take the necessary precautions to prevent possible damage); 2) Risky drinking (the consumption of substances increases the likelihood of problems in the individual, this classification being named binge drinking when the person makes consumes large quantities of alcohol on the same occasion); 3) Harmful drinking (a poorly adapted pattern which entails some injury, be it biological, social, or psychological); 4) Dependence (an altered relationship between 
the individual and how he/she drinks, that is, an uncontrolled drinking associated with severe problems; Babor \& Higgins-Biddle, 2001).

Thus, the greater the alcohol drinking, the higher the likelihood of alcohol-related problems (Anderson, Braddick, Reynolds, \& Gual, 2012).

Concerning the consequences arising from alcohol use, the WHO report showed that $28.7 \%$ of all deaths corresponded to injuries, $21.3 \%$ to digestive diseases, $19 \%$ to cardiovascular diseases, $12.9 \%$ to infectious diseases, and $12.6 \%$ to neoplasias. In relation to the years of life lost as a result of abusive alcohol use, $49 \%$ are related to mental health conditions, and $40 \%$ associated with injuries (WHO, 2018).

According to the same report, about 2.3 billion people drink alcohol. The total consumption of alcohol per capita in the world population above 15 years of age increased from 5.5 liters in 2005 to 6.4 liters in 2010, maintaining this threshold in 2016. In Brazil, consumption in 2016 was 7.8 liters of pure alcohol, still a notable decrease when comparing the data with 2010, in which consumption was 8.8 liters. However, Brazil shows a higher consumption than the world average (WHO, 2018).

Even in this aspect, according to the $2^{\text {nd }}$ Household Survey on Psychotropic Drug Use, there was a significant increase in the demographic proportion related to the consumption of doses, since users often drink daily five or more doses. In 2006, $71 \%$ of respondents declared to drink up to four doses of alcohol on the same occasion, and 29\% reported drinking five or more doses. However, in 2012, the percentage of people who drank five or more doses increased to 39\% (Laranjeira, 2014).

Hence, and considering economically active part of the population, the authors sought to find studies to clarify the object of this research, and indeed, there was a study conducted by Franco and Monteiro (2016), which involved the participation of 386 eligible health sciences lecturers in public and private higher education institutions in the Midwest region of Brazil. The results showed that $64 \%$ of lecturers of private higher education institutions and $79.1 \%$ of the lecturers of the public higher education institutions drank alcohol.

A research conducted in 2012 aimed to analyze the perceptions of quality of life and health and risk factors for lecturers of a public higher education institution in southern Brazil. The participants in the study were 293 lecturers of undergraduate and/or postgraduate courses. Regarding risk factors, alcohol leads once more, presenting a $67.2 \%$ occurrence of excessive consumption of alcohol (Oliveira Filho, Netto-Oliveira, \& Oliveira, 2012).

A cross-sectional study, that aimed to verify the profile of consumption of alcohol among lecturers of a municipality in northeastern Brazil, found that $21.8 \%$ consume four or more doses on a typical day, $14.1 \%$ admitted having already caused some injuries after having drunk, and $26.3 \%$ stated that someone has already suggested that they stop drinking (Ferreira, Sales, Casotti, Bispo Júnior, \& Braga Júnior, 2011).

In this sense, yet another research that aimed to investigate the use of alcohol among technical employees of a Brazilian university showed that $38.4 \%$ reported the use of alcoholic beverages (Rigamonte, Carvalho, Muniz, \& Souza, 2016). Moreover, it is possible to observe that the problematic use of alcohol among employees of educational institutions is somehow frequent and, in this context, the authors intended to research these data among employees of a university in northern Brazil, due to situations of vulnerability to which they are subjected, such as the demotivation due to geographical distance; often unhealthy housing conditions; scarcity of leisure options, lack of minimum conditions and a physical structure to perform productive work.

The geographical location of the French-Brazilian border has many peculiarities, including the difficult access to the municipality of Oiapoque and the distance from the capital Macapá, which is approximately $600 \mathrm{~km}$ away, of which $110 \mathrm{~km}$ are not tarmac road, where the problems plaguing the northern border region intensify. Structuring programs with the implementation of $\mathrm{BI}$ is valid to associate the specificities of the French-Brazilian border and the working conditions of these employees.

The BI are a type of limited-time care, whose focus is to change patient behavior. There are several steps: evaluating the problem (screening); feedback; defining goals; discussing the pros and cons of use; counseling and developing the patient's self-efficacy. Its approach is harm reduction, seeking to reduce risky behavior and the harmful effects of this drug (Babor, Higgins-Biddle, Saunders \& 
Monteiro, 2001).

The BI technique can be applied by professionals from different areas, provided that they have received a brief training. Simple recommendations for the reduction of consumption, provided by a professional, as well as a series of resources offered in a structured treatment program, may be used (Pereira et al., 2013).

$\mathrm{BI}$ are essential, aiming to reduce this problematic, because, according to Barroso, Rosa, Jorge, and Gonçalves (2012), they are guided by the motivational approach, with the objective of identifying the risk levels of consumption of alcohol and of helping in behavioral changes for the reduction or cessation of the consumption of alcohol.

\section{Research questions}

What is the pattern of consumption of alcohol among employees of a public university, in northern Brazil? What are the variables associated with problematic consumption of alcohol?

\section{Methodology}

It was a cross-sectional, descriptive, and analytical study, conducted on a university campus in the municipality of Oiapoque, state of Amapá, in northern Brazil, in the border area with the French Guiana.

The location comprises 126 employees, and this study took a non-probabilistic sample, by convenience, of 53 public employees. The inclusion criteria were to voluntarily agree to participate in the study and to work in the institution for at least 6 months. The exclusion criteria included: the employees who, at the time of data collection, due to temporary departure, illness, maternity leave, or holiday, were absent from daily activities. All participants were informed about the nature, objectives, methodology, risks, and benefits arising out of their participation.

The data collection occurred between September to November 2017. Thus, people who voluntarily agreed to participate by responding positively to the e-mail were sent an informed consent and clarification signed by the responsible researcher, based on Resolution 466/2012 of the National Health Council, so as to en- sure the confidentiality and anonymity of the participants, along with the link to access the questionnaire on Google Docs. After answering, the participants received the confirmation of participation.

The questionnaire contained two stages: the first for the sociodemographic and working characterization of the study participants, with closed-ended questions formulated by the authors; and the second phase to identify the pattern of consumption of alcohol, using the Alcohol Use Disorders Identification Test (AUDIT). AUDIT is a globally recognized screening instrument, developed by the World Health Organization, for risk assessment concerning the consumption of alcohol in the health services of different levels and contexts. This questionnaire comprises 10 questions, covering three areas (pattern of consumption of alcohol, signs and symptoms of dependence, and problems arising from the use of alcohol). The scores vary by identifying four patterns of use: consumption not leading to problems: 0 to 7 points (low risk use - zone 1), consumption which may lead to problems: 8 to 15 points (risky use - zone 2), consumption which will lead to problems: 16 to 19 points (harmful use - zone 3), and consumption which probably already creates problems: 20 points or more (possible dependence - zone 4). The last three patterns of use are regarded as problematic use, and this instrument shows reasonable sensitivity and specificity to detect the different patterns in these cases (Babor et al., 2001).

All ethical and legal procedures were ensured. Because it is research involving humans, the project was submitted in Plataforma Brasil and forwarded to the Committee for Ethics in Research (CEP) of the Federal University of Amapá, having been approved with the CAAE no. 69869917.0.0000.0003.

Data analysis was performed in the Excel software program to allow for typo checking and necessary corrections. The data were analyzed using the IBM SPSS Statistics statistical program, version 20.0. A univariate analysis of the sociodemographic and working data was initially carried out, where the data were presented in the form of frequency tables. The chi-squared test and Fisher's exact test were used to test the significance of the variables. Scores with a $p$-value $\leq 0.05$ were considered statistically significant. 


\section{Results}

The data collected allowed observing that, as shown in Table 1, the majority of respondents were male $(56.6 \%)$, older than 30 years of age
(73.6\%), married or in a non-marital partnership (49.1\%), declared themselves brown-skinned (49.1\%), with a specialized education level (34\%), and without children (75.5\%).

Table 1

Descriptive table of demographic data of employees of the university studied ( $n=53)$

\begin{tabular}{llcc}
\hline \multirow{2}{*}{ Gender } & & $N$ & $\%$ \\
\hline \multirow{2}{*}{ Age group } & Male & 30 & 56.6 \\
& Female & 23 & 43.4 \\
\hline \multirow{3}{*}{ Marital status } & 20 to 29 years old & 14 & 26.4 \\
& $>30$ years old & 39 & 73.6 \\
\hline \multirow{4}{*}{ Skin color } & Single & 25 & 47.2 \\
& Married/non-marital partnership & 26 & 49.0 \\
& Separated & 2 & 3.8 \\
\hline \multirow{4}{*}{ Level of education } & Yellow & 1 & 1.9 \\
& Black & 5 & 9.4 \\
& White & 19 & 35.8 \\
& Brown & 26 & 49.1 \\
& Other & 2 & 3.8 \\
\hline \multirow{2}{*}{ Children } & Middle school & 2 & 3.8 \\
& High School & 5 & 9.4 \\
& Specialization & 18 & 34.0 \\
& Master's & 17 & 32.1 \\
& Ph.D. & 9 & 17.0 \\
& Post-Doc & 2 & 3.8 \\
\hline
\end{tabular}

Table 2 presents the results in relation to the working data, being that $69.8 \%$ of the respondents worked the 40-hour schedule with exclusivity. No worker in the 20-hour schedule replied to the questionnaire. Of the 53 participants, 12 were technicians and 41 lecturers, being that, in relation to the time working in the institution, the percentage of correct responses was equal to those who worked between 1 year to 2 years (34\%) and for those who worked for more than 3 years $(34 \%)$.

Table 2

Descriptive table of working data of the employees of the university studied $(n=53)$

\begin{tabular}{llcc}
\hline \multirow{2}{*}{ Work schedule } & & $\mathrm{N}$ & $\%$ \\
\hline \multirow{3}{*}{ Professional category } & 40 hours & 16 & 30.2 \\
& 40 hours (exclusivity) & 37 & 69.8 \\
\cline { 2 - 4 } & Technician & 12 & 22.6 \\
& Lecturer & 41 & 77.4 \\
& Less than a year & 2 & 3.8 \\
\cline { 2 - 4 } Working time in the institution & 1 to 2 years & 18 & 34.0 \\
& More than 2 to 2 years & 15 & 28.3 \\
& More than three years & 18 & 34.0 \\
\hline
\end{tabular}


According to the data collected, of those who responded positively to the consumption, it was found that $68 \%$ of respondents are low-risk users or abstinent, $24 \%$ are risky users; $2 \%$ have a harmful consumption, and $6 \%$ have possible dependence, as can be seen in Figure 1.
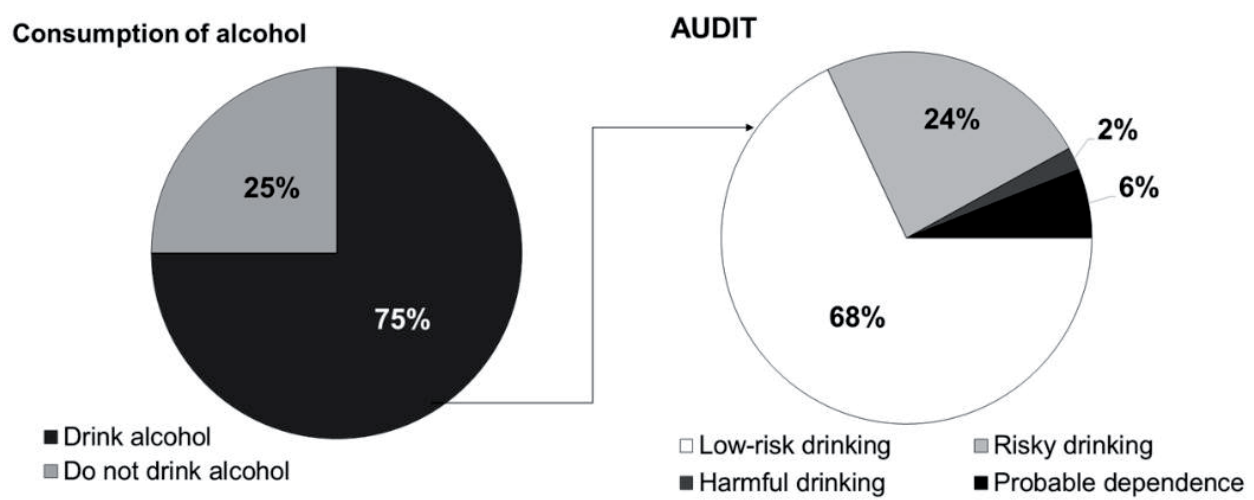

Figure 1. The patterns of consumption of alcohol among employees of the university studied.

Concerning the studied variables, only the children variable presented a statistically significant $p$-value $(p=0.03)$. The positive residual in cell
2 allows confirming that people with children have a higher probability of not manifesting a problematic consumption of alcohol (Table 3).

\section{Table 3}

Association of sociodemographic and working factors with the AUDIT scores of the employees of the university studied

\begin{tabular}{|c|c|c|c|c|c|}
\hline & \multicolumn{4}{|c|}{ AUDIT Score } & \multirow{3}{*}{$P$-value } \\
\hline & \multicolumn{2}{|c|}{$\begin{array}{c}\text { Low-risk drinking or } \\
\text { abstinence }\end{array}$} & \multicolumn{2}{|c|}{$\begin{array}{c}\text { Risky, harmful drinking, and } \\
\text { probable dependence }\end{array}$} & \\
\hline & $N$ & $\%$ & $N$ & $\%$ & \\
\hline \multicolumn{6}{|c|}{ Sociodemographic characteristics } \\
\hline Gender & & & & & 0.413 \\
\hline Male & 19 & 35.8 & 11 & 20.8 & \\
\hline Female & 17 & 32.1 & 6 & 11.3 & \\
\hline Age group & & & & & 0.734 \\
\hline$>30$ years old & 9 & 17.0 & 5 & 9.4 & \\
\hline$\leq 30$ years old & 27 & 50.9 & 12 & 22.6 & \\
\hline Marital status & & & & & 0.101 \\
\hline Single & 13 & 24.5 & 12 & 22.6 & \\
\hline Married/Partnership & 21 & 39.6 & 5 & 9.4 & \\
\hline Separated & 2 & 3.8 & 0 & 0.0 & \\
\hline Skin color & & & & & 0.27 \\
\hline Yellow & 0 & 0.0 & 1 & 1.9 & \\
\hline Black & 2 & 3.8 & 3 & 5.7 & \\
\hline White & 13 & 24.5 & 6 & 11.3 & \\
\hline Brown & 19 & 35.8 & 7 & 13.2 & \\
\hline Other & 2 & 3.8 & 0 & 0.0 & \\
\hline
\end{tabular}




\begin{tabular}{|c|c|c|c|c|c|}
\hline \multicolumn{5}{|l|}{ Level of education } & \multirow[t]{7}{*}{0.817} \\
\hline Middle school & 1 & 1.9 & 1 & 1.9 & \\
\hline High school & 3 & 5.7 & 2 & 3.8 & \\
\hline Specialization & 11 & 20.8 & 7 & 13.2 & \\
\hline Master's & 12 & 22.6 & 5 & 9.4 & \\
\hline $\mathrm{PhD}$ & 7 & 13.2 & 2 & 3.8 & \\
\hline Post-Doc & 2 & 3.8 & 0 & 0.0 & \\
\hline \multicolumn{6}{|c|}{ Work Schedule and Professional Category } \\
\hline \multicolumn{5}{|l|}{ Work Schedule } & 0.933 \\
\hline 40 years & 11 & 20.8 & 5 & 9.4 & \\
\hline 40 years (exclusivity) & 25 & 47.2 & 12 & 22.6 & \\
\hline \multicolumn{5}{|l|}{ Professional Category } & 0.915 \\
\hline Technician & 8 & 15.1 & 4 & 7.5 & \\
\hline Lecturer & 28 & 52.8 & 13 & 24.5 & \\
\hline \multicolumn{5}{|l|}{ Children } & $0.041^{\mathrm{a}}$ \\
\hline No & 24 & 45.3 & 16 & 30.2 & \\
\hline Yes & 12 & 22.6 & 1 & 1.9 & \\
\hline \multicolumn{5}{|c|}{ Work time in the institution } & 0.806 \\
\hline Less than a year & 2 & 3.8 & 0 & 0.0 & \\
\hline 1 to 2 years & 12 & 22.6 & 6 & 11.3 & \\
\hline More than 2 to 3 years & 10 & 18.9 & 5 & 9.4 & \\
\hline More than 3 years & 12 & 22.6 & 6 & 11.3 & \\
\hline
\end{tabular}

Note. ${ }^{a}$ Fisher's exact test. 


\section{Discussion}

Regarding the research variables, it was found that men have a more prevalent use of alcohol. These data are consistent with a survey conducted by the WHO, which highlighted that men presented a higher level and pattern of consumption and association with mortality and morbidity. The deaths by alcohol-related causes are $7.7 \%$ in men, while in women they are $2.6 \%$. The amount consumed was 19.4 liters in males and 7 liters in females (WHO, 2018). In a survey conducted in Brazil, men also stand out as the more frequent consumers found in the federal capital and those who consume less in the capital of a northern Brazilian state. This study, with 3,000 participants, concluded that the consumption of alcohol in relation to gender, in 2006, was $65 \%$ for men and $41 \%$ for women. In 2012, it was $62 \%$ for men and 38\% for women. Although the reduction between both genders was proved in the period from 2006 to 2012, the male gender still leads the consumption of alcohol (Laranjeira, 2014).

Moreover, a research that aimed to associate risk factors for chronic non-communicable diseases with sociodemographic variables of employees of a public higher education institution, with 225 employees, concluded that there is a greater prevalence of factors for the development of chronic non-communicable diseases associated with the variables gender, age, and education, in which men present greater consumption (Nascimento et al., 2015). Comparing the results of this research, which pointed to the existence of a higher consumption of alcohol among men, a study showed a clear association between some cultural issues and the fact that younger women have easy access to free drinks, which favors binge drinking in this population, thus increasing the health risks (Wagoner et al., 2012).

A research carried out to estimate the pattern of consumption of alcohol among employees of a public service, which counted with the participation of 322 individuals, showed an apparent prevalence of pattern of risky use, harmful use, and probable dependence associated with male employees and the low level of education. These results are consistent with the data found in this research, as to gender and level of education (Brites \& Abreu, 2014).
As regards the data from the abusive consumption of alcohol in Brazil, based on the result of national health research in 2013, a study conducted by Garcia and Freitas (2015) showed a higher prevalence of abusive use of alcohol among men $(21.6 \%)$ compared with women $(6.6 \%)$. A higher prevalence was also observed among young adults (18 to 29 years old), with a prevalence of $18.8 \%$, while the prevalence was $17.8 \%$ between 30 to 39 years old. Another study that contradicts the data of this research is the WHO report (2018), which showed that, in the age group between 20 and 39 years, approximately $13.5 \%$ of the total number of human deaths are associated with alcohol.

Regarding the age range, the study by Brites and Abreu (2014) presented a higher consumption of alcohol, both low-risk and abusive, in people with more than 36 years of age, followed by the age group of 18-35 years. On the other hand, in the study of Maciel et al. (2012), which studied the prevalence of consumption of legal and illegal drugs among secondary school teachers from public and private schools in the city of Caruaru-PE, indicated the age group between 31 to 40 years of age as major consumers of alcohol.

Furthermore, the presence of alcohol is evident among the different age groups, pointing to the popularity of alcohol in various social spheres. The survey conducted by Nascimento et al. (2015) showed that the proportion of consumption of alcohol among adolescents has been increasing, from when they first drank alcohol to when they started to drink regularly, considering the age group from 14 to 17 years. However, the higher prevalence of regular consumption of alcohol is from 18 years onward. The association between consumption of alcohol and marital status is controversial, taking into account the variety of results that some researches argue. The study by Jomar, Abreu, and Griep (2014) concluded that among non-married the proportion of risky use, harmful use, and probable dependence was higher than among married people, while the research by Brites and Abreu (2014) noted a mild expression of consumption of alcohol among married people. In this sense, the analysis of data relating to the marital status should be cautious.

In relation to skin color, these data are also controversial. In the study by Brites and Abreu 
(2014), the prevalence was $16.6 \%$ for black color compared with white color, whose prevalence was $12.4 \%$. In the study by Garcia and Freitas (2015), which aimed to describe the prevalence of abusive consumption of alcohol in the Brazilian population according to sociodemographic and health characteristics, in 2013, showed the most significant use of alcohol in black-skinned people (16.6\%), in comparison with the white-skinned (12.4\%). Among people with brown skin color, the prevalence was $14.4 \%$, and $12.6 \%$ among indigenous peoples.

As it is difficult to establish a general profile for consumers with this variable, it can be concluded that alcohol affects different social layers, assuming different roles, and causing immediate and long-term damage, according to researches cited throughout this article. This topic becomes, therefore, slightly pressing because, currently, it is difficult to discuss social interactions without the consumption of alcohol.

Only the children variable presented statistical association in this research, meaning that employees with no children manifest a higher probability of problematic consumption of alcohol. Therefore, it can be affirmed that employees with children seek to limit their consumption of alcohol so that their children are not encouraged to use this substance. Parents' behaviors are reflected on their children's, proving then that parents worry that their children will consume alcohol, thus reducing or even ceasing their consumption of alcohol as a discouragement measure.

In this context, it is valid to point out that the consumption of alcohol, often used as a distress relief, reveals a veiled and worrying scenario of the existing educational system in Brazil (Franco \& Monteiro, 2016).

Therefore, the problematic use of alcohol in the general population becomes evident, and in respect to the studied employees a distinctive look is necessary because the majority of these employees came from other regions of the country or state capital, leaving their family and friends, venturing into another reality of life, where the lack of options for fun and leisure makes their adaptation much more difficult.

Also important is the fact that the campus is very recent and is still under construction, leading to the issue of poor working conditions, associated with the lack of leisure/entertainment in the city, which can become a risk factor for the consump- tion of alcohol.

The lecturers, in addition to minister the classes, have to write articles, guide students, make presentations at congresses, master's, doctorates, reports, and such. The administrative technicians also have a hectic routine, since the needs of a campus with more than 800 students require agile employees.

This research sought to associate the specificities of the French-Brazilian border and the working conditions of these employees and used the results of this study to devise strategies that will improve the quality of life of these professionals and adopt measures that prevent the abusive and problematic drinking among this population.

Hence, the results suggested a problematic consumption of alcohol in a significant portion of the sample studied, the implementation of BI being necessary within the context of work.

Although this research presents results of the pattern of consumption of alcohol among employees of a university within a context so specific, it is noted, within the limitations of this study, that some professionals did not respond to the survey, possibly because they may have been afraid of sharing personal information, even due to the methodology applied, although the confidentiality and anonymity were assured. Given the above, there may have been a bias in the presentation of results, concerning the non-totality or non-majority of the respondents that make up the educational institution studied. However, the presented data do not eliminate the damage caused by the ingestion of alcohol, and the results of this research indicated that a specific group has already presented problems related to consumption of alcohol.

Thus, the elucidation of the results of this research, the same cannot be generalized to other populations and contexts, can contribute to the educational managers reflect about the working conditions and life habits of employees of the institution, guided in a perspective that aims to improve the quality of life, and develop tools for the transformation of reality.

In conclusion, this research allows breaking barriers and creating discussions about the poor mental health to which employees are exposed, reduced quality of life due to work, to redefine health care to the employees of the French-Brazilian border. 


\section{Conclusion}

The university employees manifested a pattern of consumption of alcohol, the most significant being the low-risk drinking, followed by risky use, probable dependence, and harmful use. Due to the limitations of this research, which influenced the size of the sample, it is essential to stress the relevance of subsequent studies, to compare the results and make the most reliable data, regarding the context of the university campus studied.

It must be noted that the sample was limited, which may interfere with the results. However, the obtained data can show to the university the risks that their employees work with due to inadequate working conditions. As a result, the university may define goals to provide better working conditions to these professional groups, thus avoiding the loss of quality of work. Due to the lack of previous researches in the target population, this study contributed to establishing the pattern of consumption of alcohol in this population. This was the greatest possible outcome of this study.

Considering the damage caused by alcohol in the general lives of individuals, and because a particular group has presented problems related with the consumption of alcohol, there should be an approach with educational activities, aiming at further guidance and clarification about the damage caused by drinking, taking into account also that even those without risky use drink alcohol.

For that reason, this study is valid in the area of nursing and presents itself as a public health measure, in order to guide mandatory measures for the prevention of negative consequences and to delineate actions that delay or prevent mental illness and/or problematic consumption of alcohol among the studied population.

Lastly, the results revealed the need to adopt educational strategies in the use of alcohol, to deepen the knowledge of factors associated with the adoption of habits of alcohol ingestion, as well as to promote discussions that may decrease the problematic use of alcohol.

\section{References}

Anderson, P., Braddick, F., Reynolds, J., \& Gual, A. (2012). Alcohol policy in Europe: Evidence from AMPHORA.
Retrieved from http://www.drugs.ie/resourcesfiles/ ResearchDocs/Europe/Research/2012/Alco_Policy_ Euro_Evidence_From_Amphora_2012.pdf

Babor, T. F., \& Higgins-Biddle, J. C. (2001). Brief intervention for hazardous and harmful drinking: A manual for use in primary care. Retrieved from https://apps. who.int/iris/bitstream/handle/10665/67210/WHO_ MSD_MSB_01.6b.pdf?sequence $=1$ \&isAllowed $=\mathrm{y}$

Babor, T. F., Higgins-Biddle, J. C., Saunders, J. B., \& Monteiro, M. G. (2001). AUDIT, the alcohol use disorders identification test: Guidelines for use in primary health care. Retrieved from http://apps.who.int/iris/ bitstream/handle/10665/67205/WHO_MSD_MSB_01.6a.pdf?sequence $=1$

Barroso, T. M., Rosa, N. R., Jorge, F. M., \& Gonçalves, C. S. (2012). Drinking among adolescents and young adults: Outcome of brief intervention. Alcoholism (Clinical and Experimental Research), 36(2), $131 \mathrm{~A}$. doi: 10.1111/j.1530-0277.2012.01917.x

Brites, R. M., \& Abreu, A. M. (2014). Padrão de consumo de bebidas alcoólicas entre os trabalhadores e perfil socioeconômico. Acta Paulista de Enfermagem, 27(2), 93-99. doi:10.1590/1982-0194201400018

Ferreira, L. N., Sales, Z. N., Casotti, C. A., Bispo Júnior, J. P., \& Braga Júnior, A. C. (2011). Perfil do consumo de bebidas alcoólicas e fatores associados em um município do nordeste do Brasil. Cadernos de Saúde Pública, 27(8), 1473-1496. doi:10.1590/ S0102-311X2011000800003

Franco, L. C., \& Monteiro, P. S. (2016). Padrão de consumo de álcool e tabaco entre professores universitários. Revista Baiana de Enfermagem, 30(2), 1-11. doi:10.18471/rbe.v30i2.15860

Garcia, L. P., \& Freitas, L. R. (2015). Consumo abusivo de álcool no Brasil: Resultados da pesquisa nacional de saúde 2013. Epidemiologia e Serviços de Saúde, 24(2), 227-237. doi:10.5123/S1679-49742015000200005

Hernandez Reyes, V. E., Hernandez Castro, V. H., \& Aguila Gurierres, Y. (2015). La promoción de salude en el ámbito escolar mediante la prevención de adicciones. Revista Médica Electrónica, 37(3), 246-262. Retrieved from http:// scielo.sld.cu/scielo.php?script $=$ sci_arttext $\&$ pi$\mathrm{d}=$ S1684-18242015000300007\&lng=es\&nrm=iso

Jomar, R. T., Abreu, A. M., \& Griep, R. H. (2014). Patterns of consumption of alcohol and associated factors among adult users of primary health care services of Rio de Janeiro, Brazil. Ciência \& Saúde Coletiva, 19(1), 27-38. doi:10.1590/1413-81232014191.2009

Laranjeira, R. (2014). Segundo levantamento nacional de álcool e drogas: Relatório 2012. Retrieved from https://inpad.org.br/wp-content/uploads/2014/03/ 
Lenad-II-Relat\%C3\%B3rio.pdf

Lopes, S. V., \& Silva, M. C. (2018). Occupational stress and associated factors in public university employees of southern Brazil. Ciência \& Saúde Coletiva, 23(11), 3869-3880. doi:10.1590/1413812320182311.28682015

Maciel, S. S., Maciel, W. V., Silva, J. M., Sobral L. V., Sobral, H. V., ... Steinhauser, H. C. (2012). Prevalência do uso de drogas entre professores do ensino médio. Revista da Associação Médica do Rio Grande do Sul AMRIGS, 56(4), 295-299. Retrieved from https://www.amrigs.org.br/revista/56-4/1017

Ministério da Saúde. (2017). Vigitel Brasil 2016: Vigilância de fatores de risco e proteção para doenças crónicas por inquérito telefónico: Estimativas sobre frequência e distribuiçâao sociodemográfica de fatores de risco e proteção para doenças crónicas nas capitais dos 26 estados brasileiros e no Distrito Federal em 2016. Brasília, Brasil: Autor. Retrieved from http://portalarquivos2.saude.gov.br/ images/pdf/2018/marco/02/vigitel-brasil-2016.pdf

Nascimento, L. S., Dias, R. M., Dutra, C. D., Silva, L. M., Pedrosa, L. N., ... Araújo, J. S. (2015). Fatores de risco para doenças crónicas não transmissíveis e variáveis sociodemográficas de servidores públicos. Revista Brasileira em Promoção da Saúde, 28(2), 230-
239. doi:10.5020/18061230.2015.p230

Oliveira Filho, A., Netto-Oliveira, E. R., \& Oliveira, A. A. (2012). Qualidade de vida e fatores de risco de professores universitários. Revista da Educação Física UEM, 23(1), 57-67. doi:10.4025/reveducfis.v23i1.10468

Pereira, M. O., Angiono, B. M., Ferreira, N. C., Oliveira, M. A., Vargas, D., \& Colvero, L. A. (2013). Efetividade da intervençáo breve para o uso abusivo de álcool na atenção primária: Revisão sistemática. Revista Brasileira de Enfermagem, 66(3), 420-428. doi:10.1590/S0034-71672013000300018

Rigamonte, P. P., Carvalho, P. F., Muniz, P. T., \& Souza, O. F. (2016). Comportamento de risco dos servidores universitários. Journal of Amazon Health Sciences, 2(2),1-15. Retrieved from http://revistas.ufac.br/ revista/index.php/ahs/article/view/475/pdf

Wagoner, K. G., Blocker, J., McCoy, T. P., Sutfin, E. L., Champion, H., \& Wolfson, M. (2012). Free alcohol use and consequences: Gender differences among undergraduates. American Academy of Health Behavior, 36(4), 446-458. doi:10.5993/AJHB.36.4.2

World Health Organization. (2018). Globalstatus report on alcohol and health 2018. Retrieved from https:// apps.who.int/iris/bitstream/handle/10665/274603/ 9789241565639-eng.pdf?ua=1 
